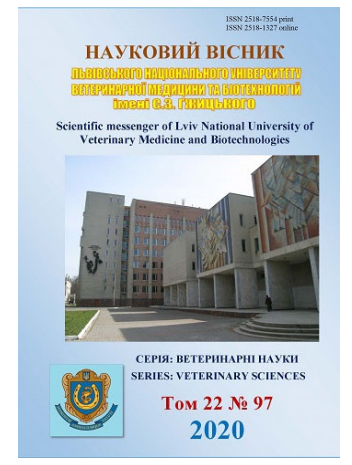

\author{
Науковий вісник Дьвівського національного університету \\ ветеринарної медицини та біотехнологій імені С.3. Гжицького. \\ Серія: Ветеринарні науки \\ Scientific Messenger of Lviv National University \\ of Veterinary Medicine and Biotechnologies. \\ Series: Veterinary sciences
}

UDC 619:616.98:619:616-076:636.8

\title{
Pathogistological changes in the lungs of Felis silvestris catus when infected with Aelurostrongylus abstrusus
}

\author{
O. M. Shchebentovska, M. V. Holubtsova
}

Stepan Gzhytskyi National University of Veterinary Medicine and Biotechnologies Lviv, Ukraine

\section{Article info}

Received 20.02.2020

Received in revised form 23.03.2020

Accepted 24.03.2020

Stepan Gzhytskyi National University of Veterinary Medicine and Biotechnologies Lviv, Pekarska St., 50, Lviv, 79010, Ukraine

Tel.: +38-067-701-81-46 E-mail: schebentovskaolga@gmail.com
Shchebentovska, O. M., \& Holubtsova, M. V. (2020). Pathogistological changes in the lungs of Felis silvestris catus when infected with Aelurostrongylus abstrusus. Scientific Messenger of Lviv National University of Veterinary Medicine and Biotechnologies. Series: Veterinary sciences, 22(97), 169-174. doi: 10.32718/nvlvet9727

Aelurostrongylus abstrusus is a parasite that belongs to Nematoda type, Metastrongyloidea superfamily, Angiostrongylidae family, Aelurostrongylus genus and is known as feline helminth, whose intermediate hosts are slugs and snails and reservoir hosts are mice and birds. In cats, Aelurostrongylus abstrusus parasitizes in bronchioles and alveoli, causing specific inflammatory changes in the lower respiratory tract and enables the development of such clinical signs as cough, shortness of breath as well as mucous-purulent discharge from the nasal cavity, when complicated by bacterial infections. Females of parasite lay eggs, which the larvae of $L_{1}$ hatch from. Subsequently, these larvae cough with bronchial mucus and are swallowed by an animal. They pass through the digestive channel without changes and together with the faeces are released into the environment. The first stage larvae actively penetrate into the body of the slugs, fade twice and are becoming invasive. Duration of larvae development from the stage $L_{1}$ to $L_{3}$ depends on the biological cycle of intermediate hosts - slugs and snails. Cats are becoming infected by eating slugs or snails with invasive larvae of the third stage $\left(L_{3}\right)$, which are transmitted from the digestive channel of the definitive host (cat) with blood flow to the lungs. Usually, the pathogen has low pathogenicity and invasions are primarily detected after animal's death, during pathoanatomical dissection. Acute clinical signs of the disease have not been described much up to date. The article presents the results of pathomorphological examination of the cat's lungs infected by Aelurostrongylus abstrusus. The severity of pathomorphological changes of the cat's pulmonary tissue depends on the intensity of the invasion. When dissected, the lungs appear unevenly coloured, dark red with light and slightly denser areas, where focal parasitic nodules are clearly distinct, surrounded by pink halo and different in size but mostly round, dense consistency. Main morphological characteristic of Aelurostrongylus abstrusus infection is the presence of numerous eggs and $L_{1}$ larvae in the alveoli but also in the bronchi. Helminth eggs accumulated in the alveolar lumps, surrounded by a thin shell; a severe cellular reaction from lymphocytes, macrophages and histiocytes occurred around this shell. An inflammatory reaction resulted in the thickening of the interstitial tissue with a strong vascular response, characterized by fraying and edema of the vessel walls. The results of pathomorphological researches have shown that the main changes were localized in the lungs and bronchial tubes with diffuse damage of the pulmonary tissue parenchyma and development of croupous pneumonia.

Key words: Arion lusitanicus, pulmonary nematodes, helminth eggs, larvae, alveoli, focal necrosis, parasitic nodes, pneumonia.

\section{Патоморфологічні зміни в легенях кота свійського (Felis silvestris catus) інвазованого Aelurostrongylus abstrusus}

\author{
О. М. Щебентовська, М. В. Голубцова
}

Львівський національний університет ветеринарної медицини та біотехнологій імені С. 3. Гжсицького, м. Львів, Украӥна 
Aelurostrongylus abstrusus - nаразит, щз належить до типу Nematoda, надродини Metastrongyloidea, poдини Angiostrongylidae, роду Aelurostrongylus відомий як котячий легеневий гельмінт, проміжними господарями якого є слизні та равлики, резервуарними миші, птахи та ящірки. Паразитує Aelurostrongylus abstrusus в бронхіолах $і$ альвеолах, викликаючи специфічні запальні зміни у нижніх дихальних шляхах з розвитком у котів таких клінічних проявів, як кашель, задишка, при ускладненнях бактеріальними інфекціями - слизисто-гнійні виділення з носової порожснни. Самки паразита відкладають яйця з яких вилуплюються личинки L. В подальшому ці личинки відкашлюються з бронхіальним слизом і заковтуються твариною. Через травний канал вони проходять без змін і разом з фекаліями виділяються у зовнішнє середовище. Личинки першої стадї активно проникають в тіло слизнів, двічі линяють та стають інвазійними. Тривалість розвитку личинки від стадії $L_{1}$ до L3, найчастіше, залежить від біологічного ичиклу проміжних господарів - слизнів і равликів. Коти заражаються при поїданні слизнів або равликів з інвазійною личинкою третьої стадї (L3), яка з травного каналу дефінітивного господаря (кота) з током крові та лімфою переноситься до легень. Зазвичай, збудник має низьку патогенність і найчастіше інвазію виявляють вже після загибелі тварини при проведенні патологоанатомічного розтину. Гострі клінічні прояви захворювання практично не описані. У статті представлені результати патоморфологічного дослідження легенів кота, інвазованого нематодою Aelurostrongylus abstrusus. Вираженість патоморфологічних змін у легеневій тканині котів, у значній мірі, залежить від інтенсивності інвазіі. На розтині легені нерівномірно забарвлені, темно червоного кольору з світлими, дещо ущільненими ділянками, де чітко візуалізувались фокальні паразитарні вузлики, оточені рожевим ореолом, різні за розміром, переважно округлої форми, на розрізі щільної консистенції. Основною морфологічною ознакою ураження Aelurostrongylus abstrusus була наявність в альвеолах численних яєць та личинок на стадї $L_{1}$, які також знаходили $і$ в бронхах. Яйчя гельмінтів нагромаджувались в альвеолярних просвітах, були оточені тоненькою оболонкою, навколо якої виникала виражена клітинна реакція з лімфоцитів, макрофагів та гістіоцитів. Запальна реакція призводила до потовщення інтерстиціальної тканини з характерною судинною реакцією, розволокненням та набряком стінок судин. Результати патоморфологічних досліджень показали, щуо основні зміни локалізувались у легенях та бронхах з дифузним ушкодженням паренхіми легеневої тканини та розвитком крупозної пневмонії.

Ключові слова: Arion lusitanicus, легеневі нематоди, яйця гельмінтів, личинки, альвеоли, фокальний некроз, паразитарні вузлики, пневмонія.

\section{Вступ}

Органи дихання є місцем локалізації багатьох видів круглих червів у ссавців, птахів, земноводних i плазунів. Залежно від циклу розвитку паразита, личинки займають строго специфічні ділянки в органах дихання, куди потрапляють через кровоносну та лімфатичну систему, найчастіше із травного тракту (Neviadomska et al., 2006).

Сьогодні в європейських країнах, а також і в Україні, приділяється велика увага до вивчення клінічних особливостей та морфологічних змін у домашніх та диких котів за ураження нематодами, які викликають патології в органах дихання та серцево-судинній системі (Conboy, 2009; Traversa et al., 2010; Traversa \& Di Cesare, 2013; Brianti et al., 2014). Опубліковані наукові статті щодо епізоотичної ситуації по хворобах котів, інвазовані Aelurostrongylus abstrusus (Railliet, 1898), свідчать про широкий ареал цього захворювання у країнах Європи. Проблема аелюростронгільозу існує у Швеції (Grandi et al., 2017), Німеччині (Lange et al., 2018), Данії (Olsen et al., 2015), розповсюджена у регіонах Греції (Symeonidou et al., 2018), Італії (Di Cesare et al., 2015; Di Cesare et al., 2015), Португалії (Nabais, et al., 2014), Сербіï (Gavrilović et al., 2017) та інших країнах.

За сучасною класифікацією, збудник Aelurostrongylus abstrusus котів, належить до типу Nematoda, класу Chromadorea, ряду Rhabditida, підряду Strongylida, надродини Metastrongyloidea, родини Angiostrongylidae, роду Aelurostrongylus (Elsheikha et al., 2016).

Aelurostrongylus abstrusus є біогельмінтом, проміжними господарями якого є різні види слизнів (Arion lusitanicus, Limax maximus) і равликів (Helix aspersa, Achatina fulica), резервуарними - миші, птахи, ящірки. Дорослі особини Aelurostrongylus abstrusus паразитують в легеневій тканині та бронхах і є яйцеживород- ними. Самки паразита відкладають яйця з яких вилуплюються личинки $\mathrm{L}_{1}$. В подальшому ці личинки відкашлюються з бронхіальним слизом і заковтуються твариною. Через травний канал вони проходять без змін і разом з фекаліями виділяються у зовнішнє середовище. Личинки першої стадії активно проникають в тіло слизнів, двічі линяють та стають інвазійними, там вони можуть тривалий час зберігатись. Тривалість розвитку личинки від стадії $\mathrm{L}_{1}$ до $\mathrm{L}_{3}$, найчастіше, залежить від біологічного циклу проміжних господарів - слизнів і равликів. Коти заражаються при поїданні слизнів або равликів з інвазійною личинкою третьої стадії $\left(\mathrm{L}_{3}\right)$, яка 3 травного каналу дефінітивного господаря (кота) з током крові та лімфою переноситься до легень. Інкубаційний період триває від 4 до 6 тижнів, патентний період - близько 4 місяців, проте деякі гельмінти можуть жити в легенях декілька років, але при діагностиці личинки будуть відсутні у калі (Traversa \& Di Cesare, 2014; Brianti et al., 2014).

Зазвичай збудник має низьку патогенність і найчастіше інвазію виявляють при проведенні патологоанатомічного розтину котів. Згідно $з$ літературними даними, коти, які мало рухаються, живуть в квартирах, більше знаходяться у спокої, клінічні прояви захворювання, переважно, обмежуються хронічним кашлем, тоді, як у тварин жвавих, активних, особливо при фізичних навантаженнях часто відзначають тривалий кашель і нежить, легку задишку і утворення слизового мокротиння 3 наступним розвитком інтерстиціальної бронхопневмонії (Barutzki \& Schaper, 2013). Слід зазначити, що хворіють коти незалежно від середовища в якому проживають, способу життя, породи та статі. В літературі описані випадки захворювання домашніх котів, які постійно утримувались у приміщеннях, без доступу до вигульних майданчиків. Тварини, що живуть на вулиці, мають можливість полювати на мишей, птахів, поїдати слизнів, равликів, 
звичайно, частіше уражаються гельмінтами A. abstrusus.

Незважаючи на те, що багато практикуючих лікарів ветеринарної медицини вважають елуростронгільоз спорадичним захворюванням і відносно непатогенним, останні кілька років спостерігають все більшу зацікавленість та вивчення його впливу на здоров'я не лише домашніх котів, але й диких тварин з родини котячих, яких утримують у приватних зоопарках (Mircean et al., 2010).

Поширенню хвороби на території Західної України сприяє масове розмноження проміжних хазяїв іспанських рудих слизнів (Arion lusitanicus) для яких висока температура та підвищена вологість, у зв'язку зі зміною клімату, є оптимальними для швидкого розвитку. Равлики, на нашу думку, в поширенні даного захворювання, мають другорядне значення.

Метою роботи було з'ясувати основні патоморфологічні зміни в легенях кота свійського інвазованого Aelurostrongylus abstrusus.

\section{Матеріал і методи досліджень}

Матеріал для патогістологічого дослідження відбирали від кота свійського, 4 річного віку, спонтанно інвазованого Aelurostrongylus abstrusus. Упродовж року в тварини відмічали несистематичний кашель, а за кілька днів до загибелі - підвищення температури, в межах від 39,2 до $41,1{ }^{\circ} \mathrm{C}$, апатію, втрату апетиту, важке дихання з хрипами.

Патологоанатомічний розтин проводили в прозекторії кафедри нормальної та патологічної морфології і

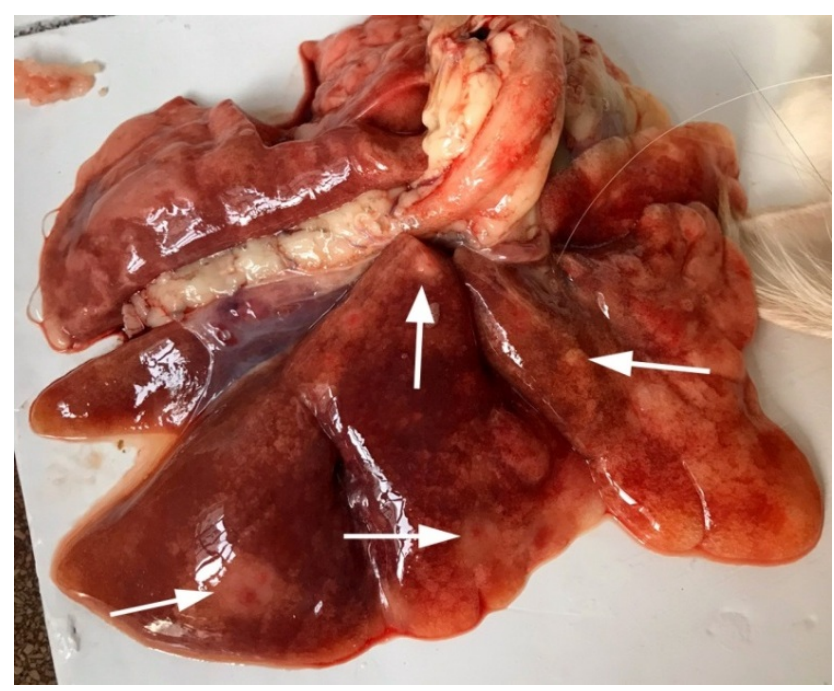

Рис. 1. Крупозна пневмонія. Паразитарні вузлики (стрілки)

Висока інтенсивність інвазії легень кота гельмінтами Aelurostrongylus abstrusus призвела до розвитку крупозної пневмонії. В уражених ділянках альвеоли були заповнені лейкоцитами та фібрином, альвеолярні перегородки деформовані. Лейкоцити та філаменти фібрину заповнювали просвіт бронхів. Міжчасточкові перегородки були набряклі. Стінки бронхів потовще- судової ветеринарії ЛНУВМБ імені С. З. Гжицького. Для гістологічного дослідження відбирали шматочки уражених легень, які фіксували у 10 \% водному розчині нейтрального формаліну. Зафіксовані у розчині формаліну фрагменти відібраних тканин зневоднювали у висхідному ряді спиртів із наступною заливкою у парафін за загальноприйнятою методикою. 3 парафінових блоків виготовляли гістозрізи товщиною 7 мкм на санному мікротомі MC-2 (Merkulov, 1953; Kiceli, 1962, Merkulov, 1969). Для світлооптичної мікроскопії парафінові зрізи фарбували гематоксиліном Маєра та еозином. Світлову мікроскопію і мікрофотографування гістопрепаратів здійснювали за допомогою мікроскопа Leica DM-2500 та фотокамери Leica DFC 450C.

\section{Результати та їх обговорення}

При проведенні патологоанатомічного розтину кота було встановлено, що тварина загинула від крупозної пневмонії. Макроскопічно легені нерівномірно забарвлені, чітко виділялись ділянки із світлим забарвленням та більшою щільністю, та темно-червоні ділянки (рис. 1), з поверхні розрізу яких витікала мутна червона чи рожева рідина. Шматочки легень у воді занурено плавали. В паренхімі легень чітко розрізняли світло рожевого та сірого кольору, переважно округлої форми, різних розмірів вузлики (рис. 2). Розміщувались вони хаотично по всій площі легеневої тканини, на розрізі були щільні та дифузні.

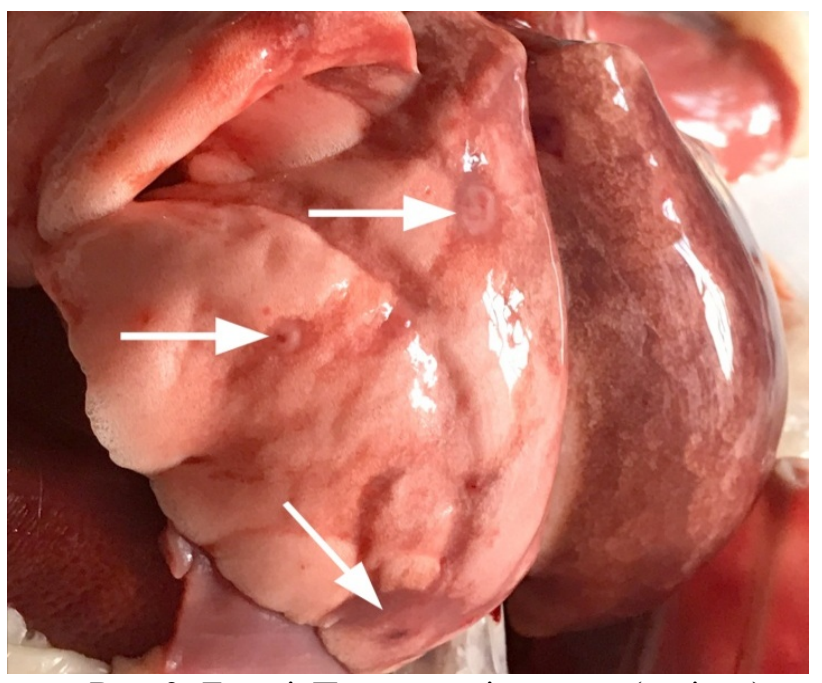

Рис. 2. Легені. Паразитарні вузлики (стрілки) в легеневій частці. Фокальний некроз

ні, набряклі, відзначалась масивна інфільтрація перибронхіальної сполучної тканини лімфоїдними клітинами, гістіоцитами та плазмоцитами 3 утворенням навколо бронхів клітинних муфт (рис. 3, 4). Судини переповнені кров'ю. Навколо судин також характерними були лімфоцитарні клітинні інфільтрати. 


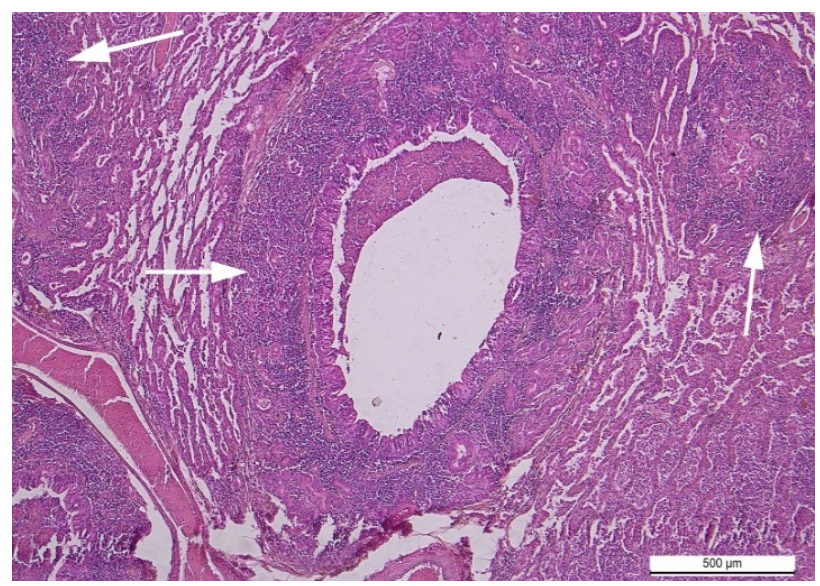

Рис. 3. Легені. Інфільтрація перибронхіальної сполучної тканини лімфоїдними, гістіоцитарними та плазматичними клітинами (стрілки). Гематоксилін та еозин. Ок. 10, об. 20

В альвеолах, де мікроскопічно виявляли яйця гельмінта, характерним було формування специфічних паразитарних вузликів (рис. 5). Ці вузлики в альвеолах і бронхіолах є результатом скупчення яєць і личинок. Альвеоли розширені, альвеолярні перегородки пошкоджені, оточені поліморфноядерними нейтрофі-

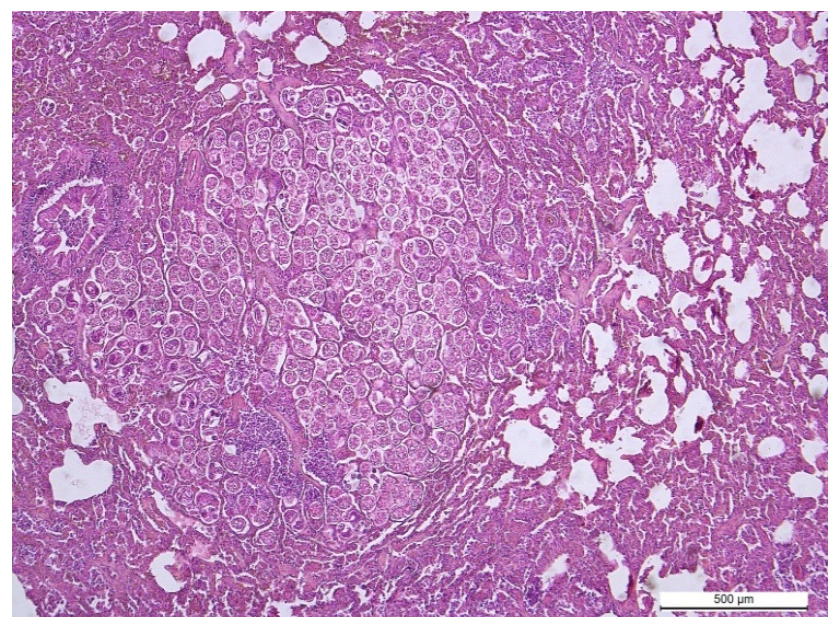

Рис. 5. Легені. Паразитарні вузлики, що містять личинки та яйця Aelurostrongylus abstrusus.

Гематоксилін та еозин. Ок. 10, об. 5

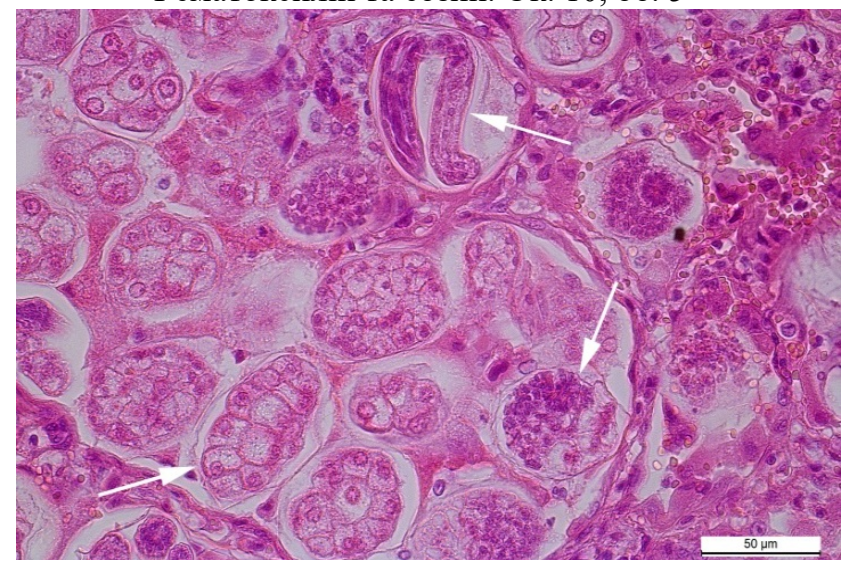

Рис. 7. Яйця Aelurostrongylus abstrusus 3

бластомерами та личинками $\mathrm{L}_{1}$ (стрілки).

Гематоксилін та еозин. Ок. 10, об. 40

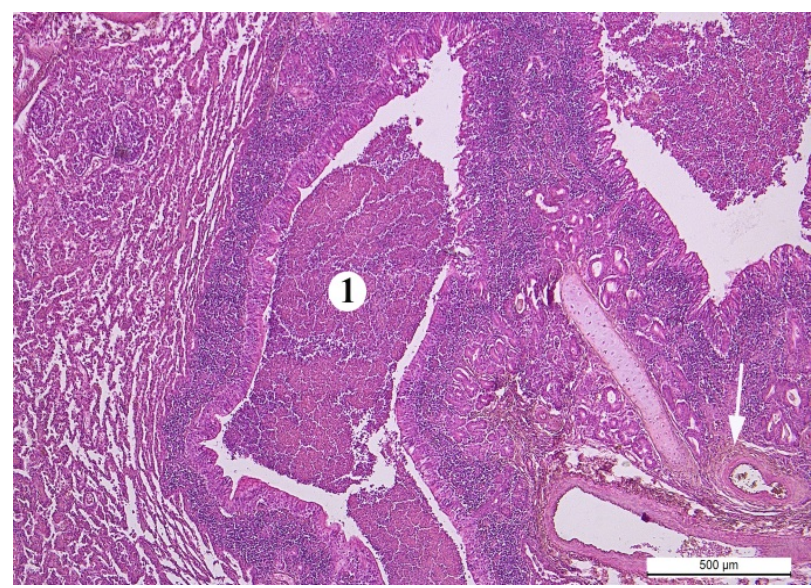

Рис. 4. Легені. Просвіт бронхів заповнений лейкоцитами (1). Розволокнення та набряк стінки судин (стрілка). Гематоксилін та еозин. Ок. 10, об. 20

лами, макрофагами та плазматичними клітинами. Яйця Aelurostrongylus abstrusus, які заповнювали альвеоли та альвеолярні ходи мали гладку тоненьку оболонку, а в середині містились морули з бластомерами (рис. $6,7,8)$.

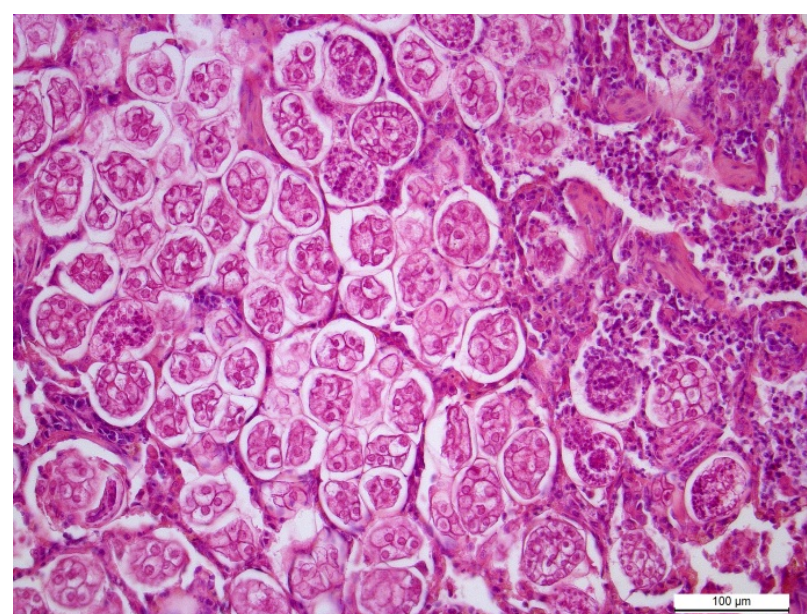

Рис. 6. Альвеоли заповнені яйцями Aelurostrongylus abstrusus $з$ бластомерами. Гематоксилін та еозин.

Ок. 10 , об. 20

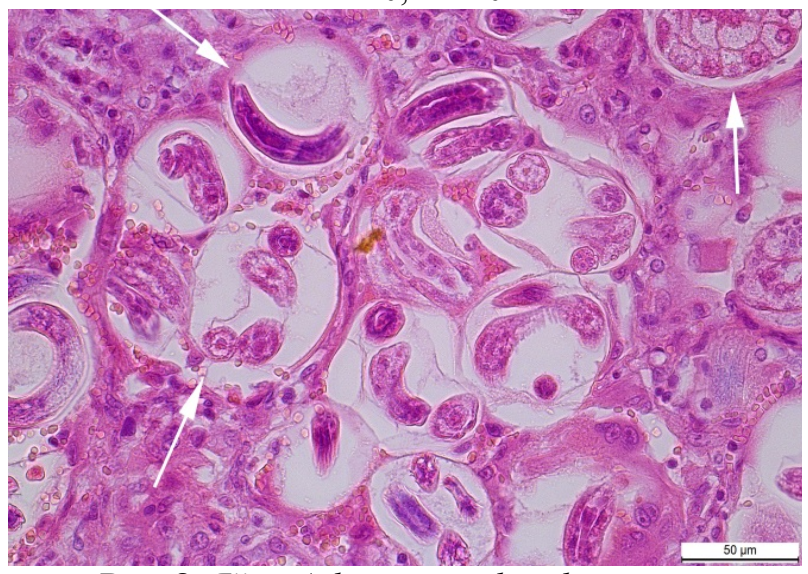

Рис. 8. Яйця Aelurostrongylus abstrusus 3

бластомерами та личинками $\mathrm{L}_{1}$ (стрілки).

Гематоксилін та еозин. Ок. 10, об. 40 


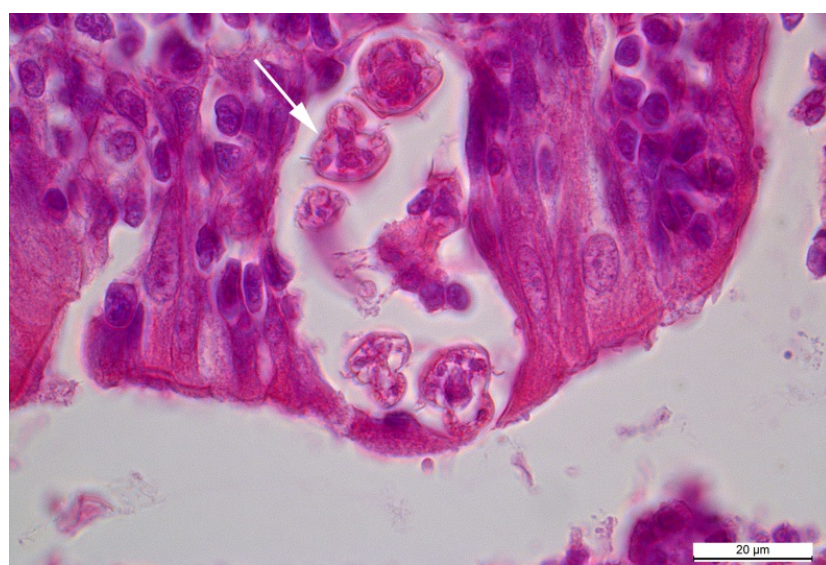

Рис. 9. Личинки, що мігрують в епітелій бронхів (стрілка). Гематоксилін та еозин. Ок. 10, об. 90

На поперечних зрізах також добре візуалізувались личинки $\mathrm{L}_{1}$. На_шляху міграції личинок до бронхів та у місцях виходу в простір, характерною була запальна реакція, набряк і крововиливи 3 подальшим потовщенням інтерстиціальної тканини.

В результаті міграції великої кількості личинок Aelurostrongylus abstrusus значні патоморфологічні зміни виявляли в паренхімі легень. Розвинулась крупозна пневмонія на стадії сірої гепатизації. Слід зазначити, що у більшості клінічних випадків гельмінтозна інвазія ускладнювалась нашаруванням секундарної сапрофітної мікрофлори. Тому, лікарі ветеринарної медицини не так часто констатують загибель тварин від гельмінтів.

\section{Висновки}

За ураження Aelurostrongylus abstrusus в легенях кота виявляли дифузне ушкодження легеневої паренхіми, значне скупчення личинок $\mathrm{L}_{1}$ і яєць в альвеолярних просвітах, інфільтрацію клітинними елементами перибронхіальної сполучної тканини та набряк артеріол.

Перспективи подальших досліджень. Проведення моніторингових гельмінтолярвоскопічних досліджень калу котів у Львівській області та виявлення антитіл до Aelurostrongylus abstrusus за допомогою серологічних тестів методом ІФА.

\section{References}

Barutzki, D., \& Schaper, R. (2013). Occurrence and regional distribution of Aelurostrongylus abstrusus in cats in Germany. Parasitol Res, 112, 855-861. doi: 10.1007/s00436-012-3207-0.

Brianti, E., Giannetto, S., Dantas-Torres, F., \& Otranto, D. (2014). Lungworms of the genus Troglostrongylus (Strongylida: Crenosomatidae): neglected parasites of domestic cats. Vet Parasitol, 202(3-4), 104-112. doi: 10.1016/j.vetpar.2014.01.019.

Conboy, G. (2009). Helminth parasites of the canine and feline respiratory tract. Vet Clin Small Anim., 39, 1109-1126. doi: 10.1016/j.cvsm.2009.06.006.

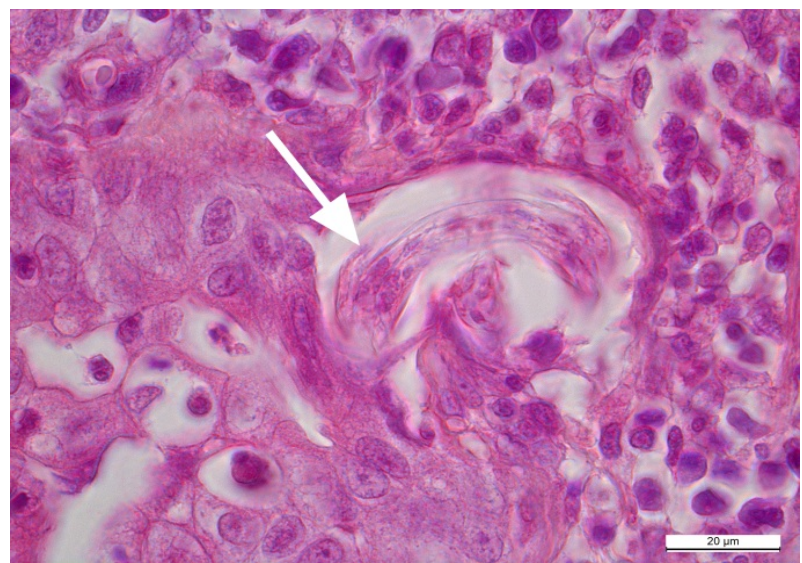

Рис. 10. Поздовжній переріз личинки $\mathrm{L}_{1}$ Aelurostrongylus abstrusus (стрілка). Гематоксилін та еозин. Ок. 10 , об. 90

Di Cesare, A., Di Francesco, G., Frangipane di Regalbono, A., Eleni, C., De Liberato, C., Marruchella, G., Iorio, R., Malatesta, D., Romanucci, M.R., Bongiovanni, L., Cassini, R., \& Traversa, D. (2015). Retrospective study on the occurrence of the feline lungworms Aelurostrongylus abstrusus and Troglostrongylus spp. in endemic areas of Italy. Vet J., 203(2), 233-238. doi: 10.1016/j.tvj1.2014.12.010.

Di Cesare, A., Veronesi, F., Grillotti, E., Manzocchi, S., Perrucci, S., Beraldo, P., et al. (2015). Respiratory nematodes in cat populations of Italy. Parasitol Res, 114, 4463-4469. doi: 10.1007/s00436-015-4687-5.

Elsheikha, H. M., Schnyder, M., Traversa, D., Di Cesare, A., Wright, I., Lacher, D.W. (2016). Updates on feline aelurostrongylosis and research priorities for the next decade. Parasites \& Vectors, 9, 389. doi: 10.1186/s13071-016-1671-6.

Gavrilović, P., Jovanović, M., Gavrilović, A., \& Nešić, S. (2017). Fatal aelurostrongylosis in a kitten in Serbia. Acta Parasitol, 62(2), 488-491. doi: 10.1515/ap-20170058.

Grandi, G., Comin, A., Ibrahim, O., Schaper, R., Forshell, U., \& Lind, E. O. (2017). Prevalence of helminth and coccidian parasites in Swedish outdoor cats and the first report of Aelurostrongylus abstrusus in Sweden: a coprological investigation. Acta veterinaria Scandinavica, 59(1), 19. doi: 10.1186/s13028-0170287-y.

Kiceli, D. (1962). Prakticheckaja mikpotehnika i gictohimija. Budapesht (in Russian).

Lange, M. K., Penagos-Tabares, F., Hirzmann, J., Failing, K., Schaper, R., Van Bourgonie, Y. R., Backeljau, T., Hermosilla, C., \& Taubert, A. (2018). Prevalence of Angiostrongylus vasorum, Aelurostrongylus abstrusus and Crenosoma vulpis larvae in native slug populations in Germany. Vet Parasitol, 254, 120-130. doi: 10.1016/j.vetpar.2018.03.011.

Merkulov, G. A. (1953). Mikpockopicheckaja tehnika. Mockva: Izdatel'ctvo inoctrannoj literatury (in Russian).

Merkulov, G. A. (1969). Kurc patologicheckoj tehniki. L. (in Russian). 
Mircean, V, Titilincu, A, Vasile, C. (2010). Prevalence of endoparasites in household cat (Felis catus) populations from Transylvania (Romania) and association with risk factors. Vet Parasitol, 171, 163166. doi: 10.1016/j.vetpar.2010.03.005.

Nabais, J., Alho, A. M., Gomes, L., Ferreira da Silva, J., Nunes, T., Vicente, G., et al. (2014). Aelurostrongylus abstrusus in cats and Angiostrongylus vasorum in dogs from Lisbon, Portugal. Acta Parasitol Portug, 20(1/2), 35-40.

Neviadomska, K., Poimanska, T., Mahnitska, B., Chubai, A. (2006). Zahalna parazytolohiia. Kyiv: Nauk. dumka (in Ukrainian).

Olsen, C. S., Willesen, J. L., Pipper, C. B., \& Mejer, H. (2015). Occurrence of Aelurostrongylus abstrusus (Railliet, 1898) in Danish cats: A modified lung digestion method for isolating adult worms. Vet Parasitol, 210, 32-39. doi: 10.1016/j.vetpar.2015.03.016.
Symeonidou, I., Gelasakis, A. I., Arsenopoulos, K., Angelou, A., Beugnet, F., \& Papadopoulos, E. (2018). Feline gastrointestinal parasitism in Greece: emergent zoonotic species and associated risk factors. Parasites \& Vectors, 11(1), 227. doi: 10.1186/s13071-0182812-x.

Traversa, D., Di Cesare, A., \& Conboy, G. (2010). Canine and feline cardiopulmonary parasitic nematodes in $\mathrm{Eu}-$ rope: emerging and underestimated. Parasite \& Vectors, 3, 62. doi: 10.1186/1756-3305-3-62.

Traversa, D., \& Di Cesare, A. (2013). Feline lungworms: what a dilemma. Trends in Parasitology, 29, 423-430. doi: 10.1016/j.pt.2013.07.004.

Traversa, D., \& Di Cesare, A. (2014). Cardio-pulmonary parasitic nematodes affecting cats in Europe: unraveling the past, depicting the present, and predicting the future. Front. Vet. Sci, 1, 11. doi: 10.3389/fvets.2014.00011. 